\title{
Development Incentive Program at Carbon Trading Activity in KPHP Tasik Besar Serkap
}

\author{
Emy Sadjati ${ }^{1}$, Muhammad Ikhwan ${ }^{1 *}$ and Ambar Tri Ratnaningsih ${ }^{1}$ \\ ${ }^{1}$ Lecturer at the Faculty of Forestry, University of Lancang Kuning, Riau, Indonesia \\ emy_mhunilak@yahoo.co.id,mmighwan@yahoo.com,ambar_trn@yahoo.com
}

*Corresponding Author

Received: 10 October 2016, Accepted: 4 November 2016

Published online: 14 February 2017

\begin{abstract}
REDD+ mechanism has been considered as an effective way to mitigate climate change in developing countries since it targets to remove carbon emissions and compensate the local communities for their conservation efforts. Incentive programs of REDD+ projects should be tailored carefully because they can cause both positive and negative effects to local communities. This research was conducted to suggest incentive program options for a peat land REDD+ project in Riau Provincial. Frequently adopted incentive programs were identified from literature review, and few more options were added based on previous local survey. Seven incentive options were finalized for the survey through discussion with KPH Tasik Besar Serkap. To figure out preference on and importance of the incentive options for local communities, questionnaire survey was conducted on 40 respondent in 2 villages around the project area. Local livelihoods activities in forest were also investigated. Collected data was used for frequency analysis and AHP analysis. Although gap between preference and importance of the options was found, the difference was minor. Among the incentive options, the respondents preferred provision of 'goods for agriculture and fishery', 'electricity generator', 'establishment of community forest' and 'job creation'. Diverse local livelihood activities in forests were confirmed, though intensity of dependence was different among the villages. It is concluded that a set of small incentive programs would lead to better results than 'one-big' incentive program, since it can provide more opportunities for local people to participate in. To develop an effective incentive program for REDD+ project, local preference, importance for local community, and impacts on local livelihood should be considered simultaneously.
\end{abstract}

Keywords: REDD+; Incentive program; Local participation; Forest livelihoods

\section{Introduction}

Since 2007, Event REDD + (Reduce Emissions from Degradation and Deforestation ) has received considerable attention as an effective mechanism for climate change mitigation. REDD+ mechanism not only helps to preserve carbon in forest areas, but it can provide the right incentive program for communities around the villages in forest areas to support sustainable forest management.

Provision of incentive programs usually already considers the protection of forest communities and be an effective means for promoting cooperation and participation of local communities in the forest areas for REDD + activitie. However, incentive programs often fail to reach their destination, because the gap between the incentives and demand and expectations of the community around the forest area.

This study aims to determine the factors that affect the communities local participation in REDD+ activities and program development right incentives in the villages around the area of REDD+ KPHP Tasik Besar Serkap. While the benefits of research of among others, to help the 
Development Incentive Program at Carbon Trading Activity in KPHP Tasik Besar Serkap

relevant stakeholders (government) in determining the priority of an incentive program that will do for the communities around the forest area.

\section{Material \& Methodology}

From several villages located near the area of REDD+, selected two villages example by the number of respondents in each village as much as 20 respondents, it is done for a limited time and funds. Selection of respondents in each village is based on the characteristics of employment and education and earnings. To determine the level of understanding of the community and also to invite the community to support and participate in REDD + projects, the variable influende level on REDD + activities should be known. These variables include the dimensions of attitudes, context, personal capacity and routines visited the REDD+. For attitude factor, paramater that measured namely the natural environment and local culture.

Parameters measured include land ownership, dependency economic communities in REDD+, and willingness to accept compensation. For measuring one personal capacity, measured parameter is socio demographic, such as age, income, education level and occupation. For routine factors, the measured parameters include frequency visiting and length of stay in area REDD+. Finally, the costs and benefits of REDD+ activities and participation will be measured. Most of the data is measured using the Likert scale.

As part of the protection of REDD + activities, the program has been designed voluntary cooperation together with the parties that have been involved. A draft list of the incentive program will be retried asked of each respondent after consultation with the relevant parties such as the forest department in Siak, and KPH Tasik Besar Serkap. For that trying to convey 7 incentive program included in the research of a questionnaire to measure the preferences of local communities.

To identify factors that influence the participation rural communities in REDD + activities, use equation modeling structural. In this survey, the AHP method is used to assess the preferences at the incentives program that given for rural communities around the KPHP Tasik Besar Serkap. Each incentive program will be compared one by one, and the average amount of each pair is evaluated to come to know the incentive program is most preferred by local communities.

\section{Results And Discussion}

\section{Characteristics of Respondents}

In the village of Rawa Mekar Jaya (RMJ), most of the respondents are male (75\%), with ages between 41 years to 50 years. Most of them were graduated of elementary school. All respondents are Muslim. In RMJ village, work varied among respondents are farmers (30\%), employees (15\%), dealers (15\%), entrepreneurs (10\%), etc. As many as 50\% of respondents living in the village of Rawa Mekar Jaya less than 20 years, and the other half live more than 20 years. While in the Penyengat village, respondents' gender balance, male (50\%) and women $(50 \%)$, and the age distribution is also relatively the same compared with RMJ village. Almost equal with RMJ village, half of the respondents in the village of Penyengat just graduated elementary school. Contrast with RMJ villages, distribution of religious respondents in the village Penyengat quite complete, and most of them are Christians and Hindus ; Islam (5\%), Christian (40\%), Hindu (30\%), Buddhists (10\%), others (10\%). As many as $50 \%$ of respondents worked as farmers, and most of them lived in the village more than 20 years $(75 \%)$.

\section{Respondents' Attitudes about Protecting the Environment}

Respondents from both villages seem to understand the importance of keeping the environment around the village. Partially of respondents demonstrated that they felt a moral responsibility to protect the environment around the area where they living. All respondents agreed that they should maintain the environment.

From the results of these answers, respondents seem to understand the importance of the natural environment around them. They can support REDD + activities more actively, if they understand the crucial role of REDD + activities clearly. However, it takes an adequate compensation for losses that 
Development Incentive Program at Carbon Trading Activity in KPHP Tasik Besar Serkap

may arise as a result of REDD + activities, so that it is able to provide assurance to them to keep the environment well.

\section{Ownership of Land in Areas of REDD +}

Ownership of land in the location of REDD +, which is claimed by local people was confirmed. In this survey, the ownership of land claimed by local people regarded as customary law because official land ownership on REDD+ locations authorized by the government ( KPH ) .

Some $30 \%$ of respondents in the village of RMJ and $50 \%$ of rural respondents of Penyengat Village claim that they own the land at the site of REDD +. As many as $70 \%$ of respondents in the village RMJ and $85 \%$ of rural respondents Penyengat answered that they have the right to use the land at the site of the REDD+. Aspects of land ownership that still leaves the problem in these villages should be verified first before REDD + activities proceed further.

\section{The level of Dependence of Livelihoods in REDD + location}

$35 \%$ of RMJ respondents, and $70 \%$ of rural respondents of Penyengat had revenues sourced from forests in the REDD + . Respondents from Penyengat shows the dependence penda higher opportunity on the location of REDD $+; 60 \%$ of respondents clicking rely on more than $40 \%$ of revenue livelihood there

Respondents from both villages have activities in the forests in the project area, while in Penyengat village showed higher numbers of livelihoods activities in forest. Dependency general livelihood Penyengat respondents are twice as many of the respondents RMJ village.

Penyengat village is adjacent to the project site from other villages, and more dependent on forests at the project site. Among the villages near the project site, the village will become one of the most affected villages, and has a high chance to cause problems of leakage or impermanence for the project. This village requires special attention to the implementation of the project.

\section{Support for REDD + Activities}

$15 \%$ of respondents of RMJ village and $30 \%$ of respondents agree that they had benefit and support from entities related to project. Other than that, some Penyengat respondents agreed that their communities benefit from the project even though his family did not receive any benefit. Although there are some program initial support including provision of seeds pineapple, less than half of the respondents agreed that their families and communities should be provided for compensation due to disappearance of opportunity local livelihoods caused by such activities, and to promote local communities for mentioned. More appropriate incentive program, which can clearly be considered as support by the local community, should be offered, and the effects of the program should be monitored for efficiency investments

\section{Impacts of REDD + Activities}

Respondents from both villages are generally agreed that the project would affect their livelihood in many aspects. Some $65 \%$ of respondents RMJ agreed that the project would affect the opportunities their jobs, and less than $50 \%$ of them agreed that other aspects such as revenue livelihoods, infrastructure development, environmental protection, land ownership conflicts and land use regime will be affected

Most respondents from Penyengat are expected the project will affect their lives in general. In all aspects, more than $70 \%$ of the respondents agreed to the future effects of the project, and not worry about them.

\section{Attitudes towards REDD +}

In general, respondents from RMJ agreed to support the project and follow the land use regulations, while less than half of the respondents Penyengat support for the project.

As mentioned above, village of Penyengat more dependent on the forests in the project area. They expected that the project will affect land ownership and land use scheme them negatively 
Development Incentive Program at Carbon Trading Activity in KPHP Tasik Besar Serkap

causing a significant loss in revenues that depend on the forest. In order to achieve the project objectives, Penyengat citizens must be convinced to support the project through negotiations or agreements.

\section{Capital 's Perception of the Importance of Sustainable Livelihoods}

REDD+ incentives given to the public must consider the sustainable livelihood both for villagers and security for the REDD+ program. In this study, the importance of the five sources of life for the people considered in the environmental assessment of sustainable ranked by the selected respondents .

Respondents rank the resources by determining the financial and social resources as the most critical resource for sustainable livelihoods. Human Resources was ranked third. These results can be accepted because the respondents consider their lives and communities as the most important issue, and the skills and abilities they were ranked third. Therefore, an incentive program for communities in the vicinity of the area of REDD+ should be more focused on those resources.

\section{Incentive Programs with Consideration of Aspects of The Financial Resources}

Of the seven program incentives offered after consultation with the parties KPHP Tasik Besar Serkap, it turns out in the form of resources, goods for the agricultural and fisheries have been selected as an incentive program that is most preferred by community. Creation of jobs related to REDD+, and the management of public lands as an additional income for those ranks 2 and 3 based on the selection of respondents.

\section{Conclusions}

Factors affecting the participation of rural communities around forest areas in REDD + activities KPHP Great Lakes Serkap include job opportunities diminished, income opportunity related to the livelihood of forest area was reduced, infrastructure development, environmental protection, as well as land ownership conflicts.

Program development of appropriate incentives in the villages around the area of REDD + KPHP Tasik Besar Serkap among others are available : materials and services for agriculture and fisheries, power generation, community forest management and job creation.

Acknowledgement. We would like to thanks to KPH Tasik Besar Serkap for supporting the accommodation. Also, we would like to appreciate to LPPM of University of Lancang Kuning.

\section{References}

[1] Institut Pertanian Bogor dan Institut Teknologi Bandung. 1997. Mengurangi Emisi Gas Rumah Kaca. Http/www.yahoo.co.id/ (10 Januari 2005)

[2] IPCC. 1995. Green House Inventory Reference Manual. IPCC WGI Technical Support Unit, hardly Center, Meteoroly Office, London Road, Braknell RG 12 2SY, United Kigdom

[3] Mac Diken, K. 1997. A. Guide to Monitoring Carbon Storage in Forestry and Agroforestry Projects. Winrock Interna-tional, Arlington, VA, USA.

[4] Saaty, T. L. (1989). Group decision making and the AHP.In The Analytic Hierarchy Process (pp. 59-67). Springer Berlin Heidelberg.

[5] Saaty, T. L. (2008). Decision making with the analytic hierarchy process. International journal of services sciences, 1(1), 83-98 